\title{
Performance and emission characteristics of biodiesel blends in a premixed compression ignition engine with exhaust gas recirculation
}

\author{
Bhaskar Kathirvelu ${ }^{1}$, Sendilvelan Subramanian ${ }^{{ }^{\dagger}}$ \\ ${ }^{1}$ Department Automobile Engineering, Rajalakshmi Engineering College, Thandalam, Chennai 602-105, India \\ ${ }^{2}$ Department of Mechanical Engineering, Dr. M.G.R Educational and Research Institute, Chennai 600-095, India
}

\begin{abstract}
This paper is based on experiments conducted on a stationary, four stroke, naturally aspirated air cooled, single cylinder compression ignition engine coupled with an electrical swinging field dynamometer. Instead of 100\% diesel, $20 \%$ Jatropha oil methyl ester with $80 \%$ diesel blend was injected directly in engine beside $25 \%$ pre-mixed charge of diesel in mixing chamber and with $20 \%$ exhaust gas recirculation. The performance and emission characteristics are compared with conventional $100 \%$ diesel injection in main chamber. The blend with diesel premixed charge with and without exhaust gas recirculation yields in reduction of oxides of nitrogen and particulate matter. Adverse effects are reduction of brake thermal efficiency, increase of unburnt hydrocarbons (UBHC), carbon monoxide (CO) and specific energy consumption. UBHC and CO emissions are higher with Diesel Premixed Combustion Ignition (DPMCI) mode compared to compression ignition direct injection (CIDI) mode. Percentage increases in UBHC and CO emissions are $27 \%$ and $23.86 \%$, respectively compared to CIDI mode. Oxides of nitrogen $\left(\mathrm{NO}_{\mathrm{x}}\right)$ and soot emissions are lower and the percentage decrease with DPMCI mode are $32 \%$ and $33.73 \%$, respectively compared to CIDI mode.
\end{abstract}

Keywords: Diesel blend, Diesel premixed compression ignition, Emission control, Exhaust gas recirculation, Jatropha oil methyl ester

\section{Introduction}

Energy is a requirement in our everyday life as a way of improving human development leading to economic growth and productivity. The return-to-renewables will help mitigate climate change is an excellent way but needs to be sustainable to ensure a sustainable future for generations to meet their energy needs. Knowledge regarding the interrelations between sustainable development and renewable energy is still limited [1]. Economic and societal development of any nation depends very much on the availability of energy sources [2]. Energy sources are essential input in the areas of any production, but unfortunately the energy sources available are not only limited in volume and quality but also whatever is available are fast getting depleted, storing is necessary for mankind to develop non-conventional sources of energy that not only fulfills the demand but also at the same time keeps the environment clean or green [3]. Biodiesel takes its place as the most promising alternative fuel because of its renewability and sustainability.
Biodiesel is made from rechargeable a natural resource that does not produce harmful byproducts. Biodiesel can be obtained from various sources like vegetable oils, recycled cooking oil, animal fats and algae, which are cost efficient and easy to make and use. Bio-diesel derived from edible, non-edible oils and animal fats can be used in diesel engines with little or no modifications [4].

Homogeneous Charge Compression Ignition (HCCI) is a promising alternative combustion technology for diesel engines with high efficiency and lower $\mathrm{NO}_{\mathrm{x}}$ and particulate matter emissions. Relative to compression ignition direct ignition engines, HCCI engines have substantially lower emissions [5-8]. The low emissions of particulate matter (PM) and $\mathrm{NO}_{\mathrm{x}}$ in HCCI engines are a result of the lean homogeneous air and fuel mixture in addition to low combustion temperatures. The charge in HCCI engine may be made lean by stratification, or with exhaust gas recirculation (EGR), or combination of these methods [9]. HCCI engines yield significant advantages but there are certain adverse effects such as the operating range of automotive engine using HCCI mode is found to be too
This is an Open Access article distributed under the terms of the Creative Commons Attribution Non-Commercial License (http://creativecommons.org/licenses/by-nc/3.0/) which permits unrestricted non-commercial use, distribution, and reproduction in any medium, provided the original work is properly cited.
Received November 27, 2016 Accepted March 13, 2017

${ }^{\dagger}$ Corresponding author

Email: sendilvelan.mech@drmgrdu.ac.in

Tel: +91-44-22293345 Fax: +91-44-23783165

Copyright (C) 2017 Korean Society of Environmental Engineers 
narrow [10], improper combustion or misfire attributed to lean fuel mix limits the minimum power output at which the engine can operate and auto-ignition is difficult to control [11]. In literature, the HCCI combustion mode has different names: PPCCI (Partially Premixed Charge Compression Ignition), PCIC (Premixed Compression Ignited Combustion), HCDC (Homogeneous Charge Diesel Combustion) [12-14].

\section{Premixed Compression Ignition (PMCI)}

Experimental investigation has been done to study the effect of Premixed Compression Ignition (PMCI) mode; in this method, two fuels are used. One fuel is injected in to the intake air, upstream of the intake valve to obtain a premixed charge. Remaining fuel is injected into the combustion chamber directly by conventional injection system. This technique reduces $\mathrm{NO}_{\mathrm{x}}$ and $\mathrm{PM}$ and thereby reduction of air pollution. It is observed that extensive research is yet to be done on the usage of bio-diesel in PMCI mode; hence an investigation is conducted to study the effect of Jatropha oil methyl ester (JOME) biodiesel as main fuel and diesel as premixed fuel.

In PMCI, combustion takes place predominantly in a premixed manner than in a diffusive manner due to homogeneous nature of the premix [15]. Moreover, with premix charge, the combustion process occurs much faster than conventional Diesel combustion, as it occurs at multiple points in the cylinder [16]. This rapid combustion causes a sharp increase in pressure and temperature inside the engine. Therefore, in PMCI lean fuel-air mixture is used to maintain the temperature and pressure low in the cylinder and this restricts the usage to low loads.

Miao et al. [17] conducted experiments to investigate the effect of EGR on combustion and emission characteristics of a direct injection diesel engine. The increase of the EGR percentage resulted in longer ignition delay and the combustion shifted to a later stage while the combustion duration was reduced. Regarding the effect of EGR on the exhaust gaseous emissions, it reduces $\mathrm{NO}_{x}$ emissions but increases other gaseous emissions. $\mathrm{NO}_{\mathrm{x}}$ emissions could be reduced significantly, whereas the smoke emission presents a sharp increase when the EGR ratio increases.

Reduced oxygen available for combustion lowers the effective air-fuel ratio. This effective reduction in air-fuel ratio affects exhaust emissions substantially [18, 19]. Mixing of exhaust gases increases specific heat results in the reduction of flame temperature. Thus combination of lower oxygen quantity in the intake air and reduced flame temperature reduces the rate of $\mathrm{NO}_{\mathrm{x}}$ formation reactions [20, 21]. The engines using EGR emit lower quantity of exhaust gases compared to non-EGR engines because part of the exhaust gas is re-circulated [22]. Kusaka et al. [23] also found that at low loads, EGR combined with intake heating can favorably reduce hydrocarbon emission with improvement in thermal efficiency. EGR was also used in a direct injection spark ignition engine as an effective way for improving fuel economy [24, 25].

Das et al. [26] used EGR to reduce $\mathrm{NO}_{\mathrm{x}}$ emissions in hydrogensupplemented SI engine without any undesirable combustion phenomena. However, the use of EGR leads to a trade-off in terms of soot emissions moreover it exhausted more unburned hydro- carbons (20-30\%) compared to conventional engines [27]. Therefore, in this work 20\% EGR was used to study the performance with JOME blend with diesel.

Aoyama et al. [28] revealed that the engine operation was stable in the air fuel ratio range of 33-44 and significantly lower $\mathrm{NO}_{\mathrm{x}}$ emission compared with diesel engine. Suzuki [29] studied homogeneous charge compression ignition diesel combustion system and reported that smoke and $\mathrm{NO}_{\mathrm{x}}$ emissions decreased but $\mathrm{HC}$, CO emissions increased as the pre-mixed ratio was increased. Kimura et al. [30] developed a new combustion concept, called modulated kinetics which reduced $\mathrm{NO}_{\mathrm{x}}$ and smoke simultaneously due to low-temperature and premixed combustion characteristics, respectively.

Torregrosa et al. [31] analyzed experimentally PCCI combustion with two injections (pilot and main) resulted in a significant reduction in emissions of $\mathrm{NO}_{\mathrm{x}}$ due to the use of high EGR rate which reduced in-cylinder oxygen content and subsequently combustion temperature. Saxena and Bedoya [32] reviewed HCCI operation which emphasis on the high load conditions and emissions characteristics and concluded that significant benefits of HCCI was that it can achieve efficiency levels and low $\mathrm{CO}_{2}$ comparable with diesel engines.

Kiplimo et al. [33] investigated the effects of spray impingement, injection parameters, and EGR on the emission of a PMCI, and concluded that higher injection pressure led to lower smoke, HC and $\mathrm{NO}_{\mathrm{x}}$ emissions. As observed from the literature, EGR is one of the most effective technique for reducing $\mathrm{NO}_{\mathrm{x}}$ emissions in diesel engines [34], as it reduces the in-cylinder temperatures and availability of oxygen.

JOMEs are well-proven alternatives to petroleum diesel [35-37]. Main reasons for choosing Jatropha oil in this work are its renewable environmental friendly nature, less expensive to cultivate with a little amount of water, grow in all climatic conditions and soils, high yield and approximately 50 years of plant life [38]. Use of Jatropha oil as fossil fuel will be a partial substitute for petroleum diesel to reduce the cost of petroleum products imported. Under these circumstances, Jatropha oil extracted and refined through transesterification becomes an attractive alternative to produce biodiesel.

Transesterification is a chemical process of transforming large, branched, triglyceride molecules of vegetable oils and fats into smaller, straight chain molecules, almost similar in size to the molecules of the species present in diesel fuel [39]. The process takes place by reacting the vegetable oil with an alcohol in the presence of a catalyst.

\section{Materials and Methods}

In the present experimental work, diesel was used as a premixed fuel along with conventional injection of JOME blend with premixed ratios of 0.25 and with or without EGR compared with the CIDI engine. Diesel fuel was injected into the intake manifold to form premixed charge. The charge was burnt along with the fuel directly injected into the cylinder. To stabilize the combustion and reduce the $\mathrm{NO}_{\mathrm{x}}$ emissions, $20 \%$ EGR was introduced. The objectives of this investigation are 
- To analyze the effect of EGR for better trade-off Soot and $\mathrm{NO}_{\mathrm{x}}$ emissions for JOME

- To check the aggregate effect of DPMCI mode with Bio-diesel blends

The tests were conducted on a single cylinder, four strokes, naturally aspirated, air-cooled Diesel engine coupled with an electrical swinging field dynamometer. The detailed technical specifications of the engine are given in Table 1. Fig. 1 is the schematic diagram of the experimental set-up. The intake manifold of the engine was modified to fit the primary fuel injector. AVL 415 Variable Sampling Smoke meter was used to measure the particulate matter in the exhaust. MRU delta 1,600 L Exhaust Gas Analyzer was used to measure $\mathrm{HC}, \mathrm{CO}$ and $\mathrm{NO}_{\mathrm{x}}$ values.

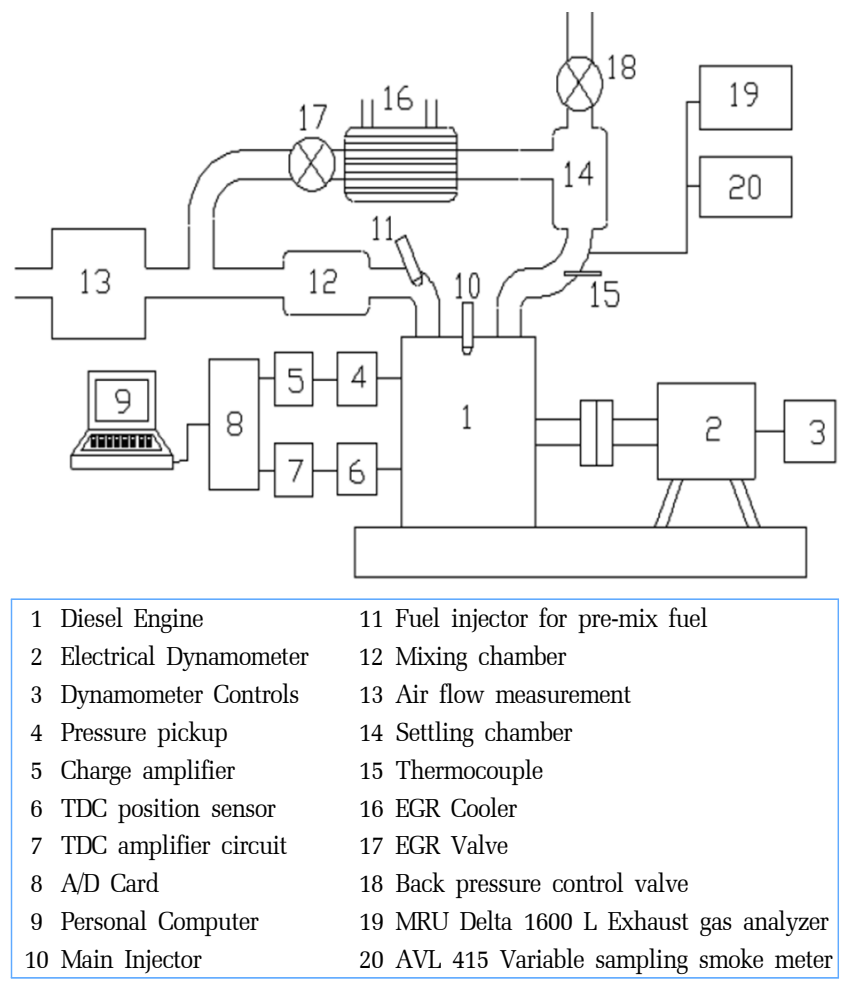

Fig. 1. Experimental setup.

Table 1. Test Engine Specifications

\begin{tabular}{ll}
\hline Engine Type & $\begin{array}{l}\text { Four stroke, Air cooled, Stationary, Constant } \\
\text { speed, Direct injection, CI engine }\end{array}$ \\
No. of Cylinders & 1 \\
Maximum Power & $4.4 \mathrm{~kW}$ at $1,500 \mathrm{rpm}$ \\
Maximum Torque & $28 \mathrm{~N}-\mathrm{m}$ at $1,500 \mathrm{rpm}$ \\
Bore & $87.5 \mathrm{~mm}$ \\
Stroke Length & $110 \mathrm{~mm}$ \\
Displacement & $661.5 \mathrm{cc}$ \\
Compression Ratio & $17.5: 1$ \\
Injection Timing & $23.40 \mathrm{CA}$ bTDC \\
Loading type & $\begin{array}{l}\text { Electrical Swinging Field Dynamometer } \\
\text { dynamometer }\end{array}$ \\
\hline
\end{tabular}

AVL 615 Indimeter system was utilized for pressure crank angle diagram at various loads using piezoelectric pressure transducer and angle encoder besides analysis of other significant parameters such as heat release rate, peak pressure, angle of occurrence of peak pressure, imep, etc. Combustion is initiated with diesel as the only fuel and engine is kept running till steady state conditions are attained. Engine Speed, fuel consumption rate, exhaust emissions ( $\mathrm{HC}, \mathrm{CO}$, and $\mathrm{NO}_{\mathrm{x}}$ ), soot, pressure-crank angle diagram and exhaust gas temperature are measured at various loads. The performance characteristics are estimated from the measured values as below:

i ) Brake thermal efficiency (BTE): Output power/ [FC $\times$ CV]

ii) Brake specific fuel consumption (BSFC): FC/ BP

iii) Brake specific energy consumption (BSEC): $\mathrm{BSFC} \times \mathrm{CV}$ [where $\mathrm{CV}$ is the calorific value of the fuel]

iv ) Fuel consumption (FC): [known quantity of fuel consumed/time taken for the known quantity of the fuel consumed] $\times$ density of the fuel

v ) Brake power (BP): $\mathrm{W} \times \mathrm{N} / \mathrm{C}$, where $\mathrm{W}$ is the load on the dynamometer, $\mathrm{N}$ is the speed of the engine and $\mathrm{C}$ is the dynamometer constant

The notations used in DPMCI mode are:

- Diesel - Diesel on a CIDI engine.

- 20\% JOME - 20\% JOME and 80\% Diesel blends on a CIDI engine.

-20\% JOME, 20\% EGR - 20\% JOME and 80\% Diesel blends on a CIDI engine with $20 \%$ Exhaust gas recirculation.

- 20\% JOME, 20\% EGR, DPMR 0.25 - 20\% JOME and 80\% Diesel blends (main fuel) with 20\% Exhaust gas recirculation along with Diesel premix ratio of 0.25 (manifold injection).

- DPMR - Ratio of energy of Diesel premix $Q_{D p}$ to total energy $Q_{t}$

$$
D P M R=Q_{D p} / Q_{t}=\left(m_{D p}{ }^{*} C V_{D p}\right) /\left[\left(m_{D p}{ }^{*} C V_{D p}\right)+\left(m_{d}{ }^{*} C V_{d}\right)\right]
$$

Where $m$ is the mass of fuel and $C V$ is lower colorific value and subscripts $D p$ and $d$ refer to Diesel premix and directly injected fuels, respectively.

\section{Results and Discussion}

Diesel fuel was injected into the mixing chamber using a solenoid operated injector controlled by Electronic Control Unit (ECU) to form premixed charge. The pre-mixed charge was burnt in the cylinder along with the fuel directly injected into the cylinder by the conventional injection system. Table 2 gives the optimum values of molar ratio, reaction temperature, catalyst and amount of catalyst used and yield of biodiesel to produce methyl ester of Jatropha in the present work. To control the start of combustion and $\mathrm{NO}_{\mathrm{x}}$ emissions, EGR technique was adopted.

Table 2. Optimum Values of Transesterification Variables

\begin{tabular}{cc}
\hline Optimized variable & Jatropha oil \\
\hline Molar Ratio of Methanol to Oil & $6: 1$ \\
Reaction Temperature in ${ }^{\circ} \mathrm{C}$ & 55 \\
Catalyst Used & Potassium Hydroxide \\
Catalyst for one Liter of Oil in g & 6.90 \\
Yield on volume basis in \% & 95 \\
\hline
\end{tabular}




\subsection{Specific Energy Consumption and Brake Thermal Efficiency}

Fig. 2 and Fig. 3 depict the variation of specific energy consumption and brake thermal efficiency with brake power for CIDI mode, 20\% JOME mode and 20\% JOME with 20\% EGR without and with premix ratio of 0.25 . The recirculation of exhaust gas increases the specific energy consumption at all the power outputs for $20 \%$ JOME, 20\% JOME, 20\% EGR with and without diesel premix. When EGR is introduced the fuel-air mix is made lean intentionally to decrease in the availability of oxygen in the charge to retard the combustion process. Increase in specific energy consumption are observed at all power outputs due the part of the premixed fuel injected into the intake port is accumulated in the premixed chamber in a liquid state at low temperature and does not enter the combustion chamber [40]. The specific energy consumption varies from $28,325 \mathrm{~kJ} / \mathrm{kWh}$ at $25 \%$ of rated output to $13,874 \mathrm{~kJ} / \mathrm{kWh}$ at rated output in DPMCI mode with $20 \%$ JOME and premix ratio of 0.25 with $20 \%$ EGR as compared to 25,140 to $12,661 \mathrm{~kJ} / \mathrm{kWh}$ in CIDI mode. The brake thermal efficiency varies from $13.05 \%$

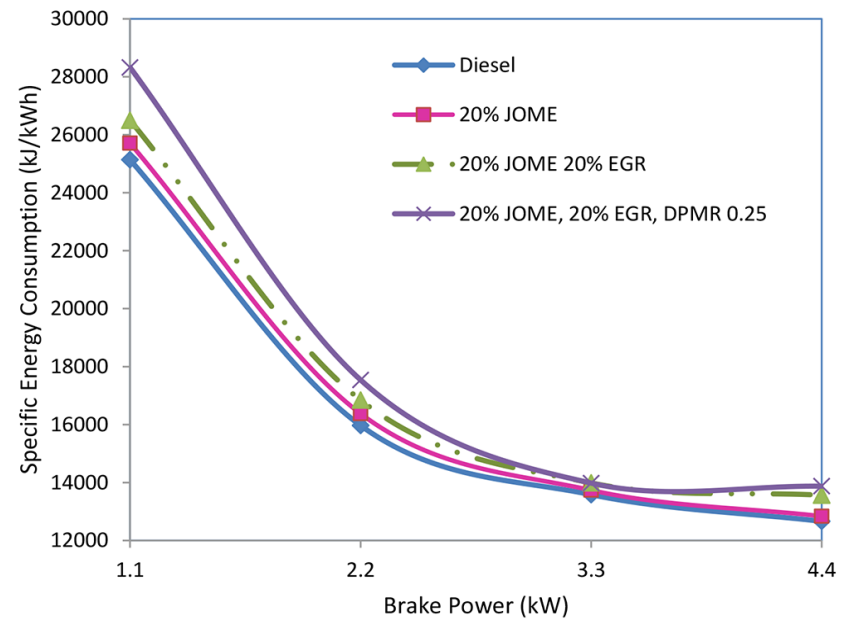

Fig. 2. Variation of specific energy consumption with brake power

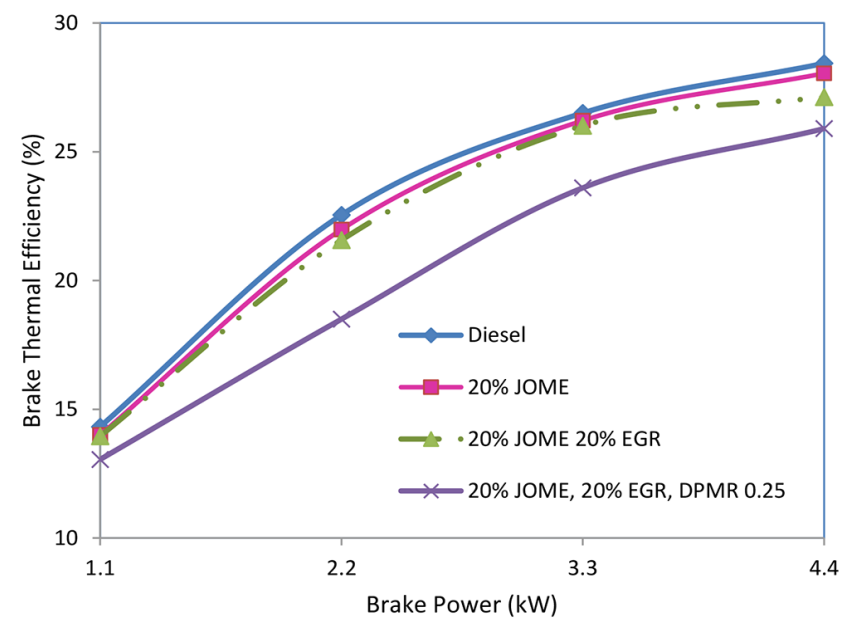

Fig. 3. Variation of brake thermal efficiency with brake power. at $25 \%$ of rated output to $25.9 \%$ at rated output in DPMCI mode with $20 \%$ JOME and premix ratio of 0.25 with $20 \%$ EGR as compared to $14.32 \%$ to $28.4 \%$ in CIDI mode. The brake thermal efficiency of $20 \%$ JOME with EGR is lower at all the power outputs compared to $20 \%$ JOME due to lower intrinsic oxygen present $(1.62 \%$ by wt.). The decrease in brake thermal efficiency are observed at all power outputs in the case of diesel premix due to the low volatility of diesel fuel results in poor vaporization and more fuel is consumed for the same power output.

\subsection{Exhaust Gas Temperature}

Fig. 4 depicts the variation of exhaust gas temperature with brake power for CIDI mode, 20\% JOME mode and 20\% JOME with 20\% EGR without and with premix ratio of 0.25 . The combustion starts much earlier resulting in higher in-cylinder temperature and pressure, these results higher exhaust gas temperature at rated power output for $20 \%$ JOME mode compared with all other modes. With EGR the specific heat capacities of re-circulated $\mathrm{H}_{2} \mathrm{O}$ and $\mathrm{CO}_{2}$ constituents increase resulting in lower peak combustion temperature. At rated power output, the exhaust gas temperature varies from $441^{\circ} \mathrm{C}$ with $20 \%$ EGR with or without premix ratio of 0.25 compared to $460^{\circ} \mathrm{C}$ without EGR (0\% EGR) in $20 \%$ JOME mode. Exhaust gas temperature is higher at higher power output for all modes. At higher power output the equivalence ratio is higher which increases the heat release and results in higher combustion pressure and temperature.

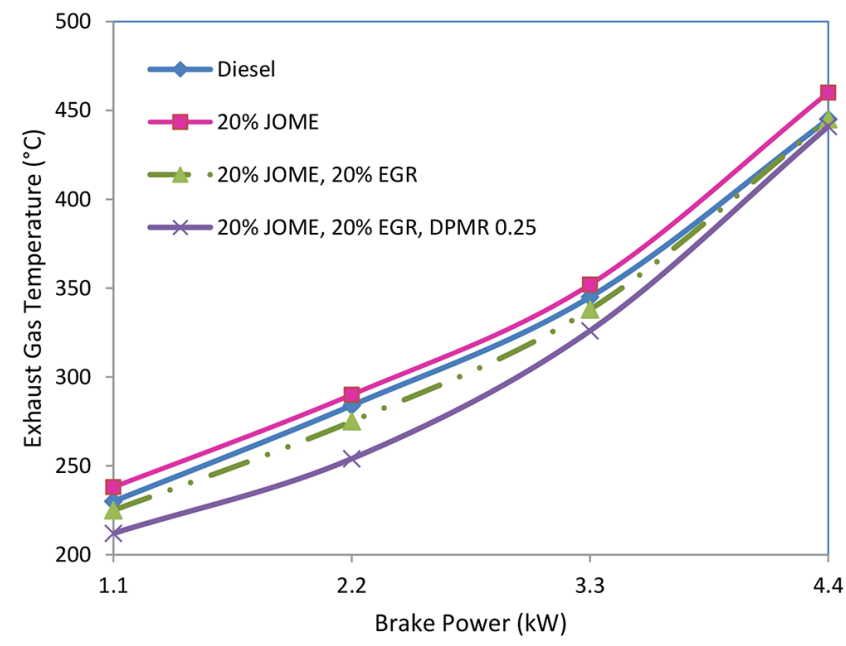

Fig. 4. Variation of exhaust gas temperature with brake power.

\subsection{Unburnt Hydrocarbon and Carbon Monoxide Emissions}

Fig. 5 depicts the variation of unburnt hydrocarbon (UBHC) with brake power in CIDI mode as well as in PMCI mode with $20 \%$ JOME with $20 \%$ EGR with or without 0.25 diesel premix. The variation of carbon monoxide emissions with brake power is depicted in Fig. 6 for the same operating conditions. A significant reduction in UBHC emissions is noticed for methyl ester blends at all the power outputs compared to diesel. This may be due to their intrinsic oxygen content (JOME-10.8 \% by wt.) whereas, diesel does not have oxygen. The carbon monoxide emission which 


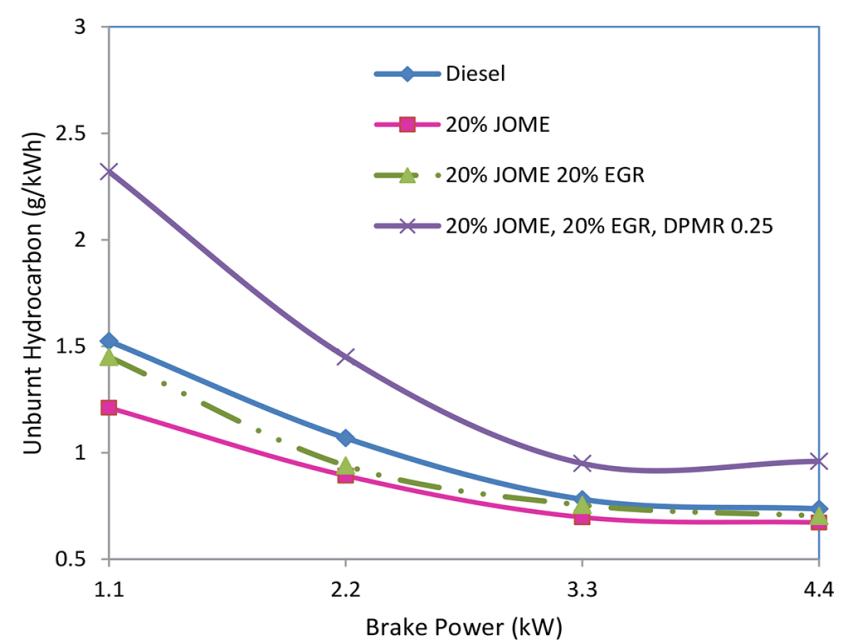

Fig. 5. Variation of unburnt hydrocarbon with brake power.

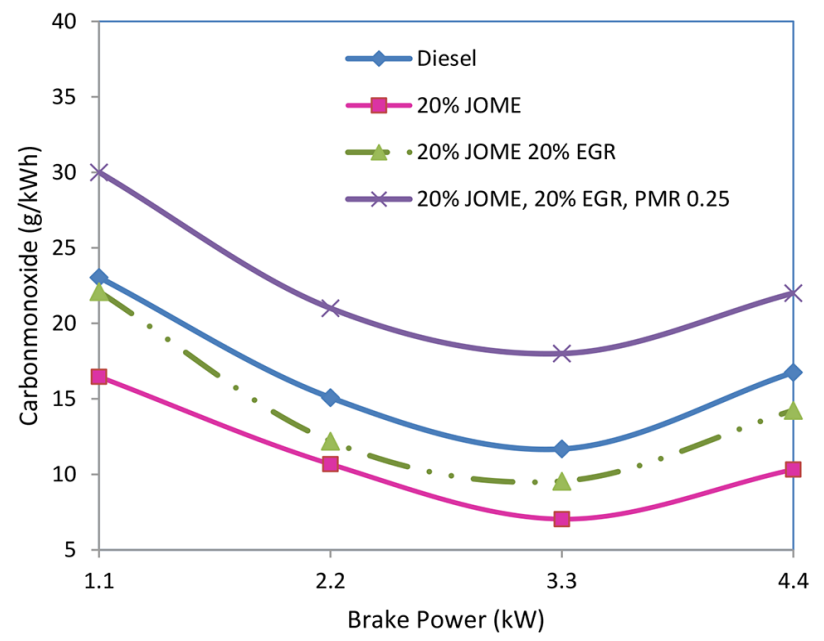

Fig. 6. Variation of carbon monoxide with brake power.

is already low in diesel engines is further reduced using methyl ester blend. Reduction of oxygen with EGR reduces the combustion rate and thereby temperature inside the cylinder. The combustion is incomplete due to less oxygen for combustion which results in higher emissions of UBHC and CO compared to $20 \%$ JOME mode. Due to lower charge temperature, premixed diesel fuel and in-cylinder injection of JOME blends don't evaporate fully which leads to higher UBHC and CO in exhaust. The effects of crevice volume and flame quenching may also be a contributing factor for high UBHC and CO emissions. The UBHC emissions vary from 2.3 to $0.96 \mathrm{~g} / \mathrm{kWh}$ in DPMCI mode with premix ratio of 0.25 and from $1.45 \mathrm{~g} / \mathrm{kWh}$ to $0.7 \mathrm{~g} / \mathrm{kWh}$ without diesel premix. The CO emissions vary from $30 \mathrm{~g} / \mathrm{kWh}$ to $22 \mathrm{~g} / \mathrm{kWh}$ in DPMCI mode with premix and $22.1 \mathrm{~g} / \mathrm{kWh}$ to $14.23 \mathrm{~g} / \mathrm{kWh}$ without premix.

\subsection{Oxides of Nitrogen in Emission}

Fig. 7 depicts the variation of $\mathrm{NO}_{\mathrm{x}}$ emissions with brake power for CIDI mode and 20\% JOME mode, 20\% JOME with 20\% EGR and $20 \%$ JOME with $20 \%$ EGR with premix ratio of $0.25 . \mathrm{NO}_{\mathrm{x}}$ emissions are reduced with EGR modes, since the available oxygen reduces; in addition to this, higher specific heat capacity of the recirculated exhaust gases lowers the global temperature in the combustion chamber, which subsequently reduces the reaction rates leading to the formation of $\mathrm{NO}_{\mathrm{x}}$ emissions. At rated power output, the $\mathrm{NO}_{\mathrm{x}}$ emissions without EGR and with 20\% EGR vary from $7.45 \mathrm{~g} / \mathrm{kWh}$ to $6.47 \mathrm{~g} / \mathrm{kWh}$ for $20 \%$ JOME. The $\mathrm{NO}_{\mathrm{x}}$ emissions at $25 \%$ of rated power output are $10 \mathrm{~g} / \mathrm{kWh}$ and at the rated power output $4.89 \mathrm{~g} / \mathrm{kWh}$ for DPMCI with $20 \%$ EGR with premix ratio of 0.25 . At rated power output the $\mathrm{NO}_{\mathrm{x}}$ emissions with $\mathrm{CIDI}$ mode is $6.47 \mathrm{~g} / \mathrm{kWh}$, which is higher than $20 \%$ JOME with EGR modes.

At rated power output, the concentration of $\mathrm{CO}_{2}$ and $\mathrm{H}_{2} \mathrm{O}$ is considerably higher and specific heat capacity increases. Both $\mathrm{CO}_{2}$ and $\mathrm{H}_{2} \mathrm{O}$ have higher specific heat capacities than air [41]. The specific heat at constant pressure $\left(\mathrm{C}_{\mathrm{p}}\right)$ of combustion products at different temperatures is shown in Table 3 [42]. At higher combustion temperatures, $\mathrm{H}_{2} \mathrm{O}$ has higher specific heat capacity than $\mathrm{CO}_{2}$. Higher heat capacity of the mixture requires more energy to pre-heat the incoming mixture, and lowers the flame temperature which reduces the $\mathrm{NO}_{\mathrm{x}}$ emissions at rated power output.

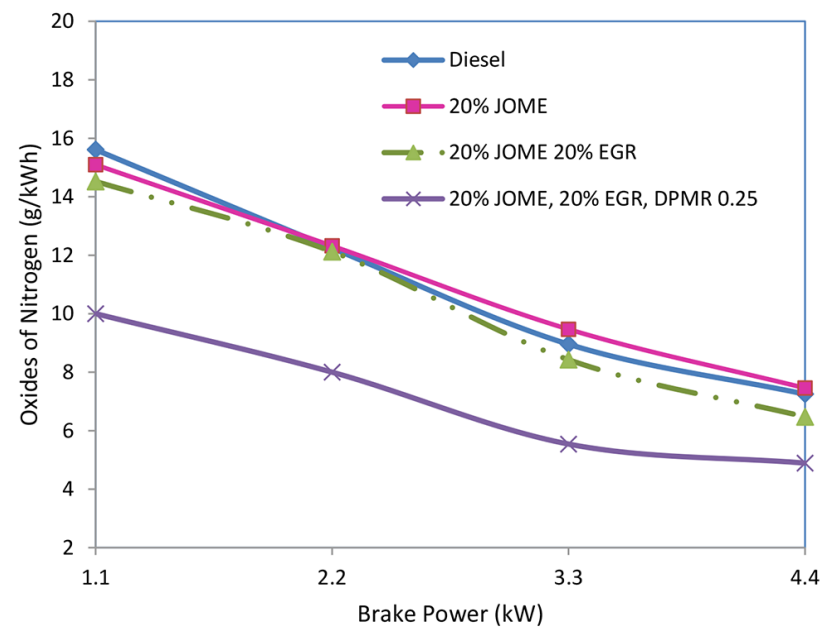

Fig. 7. Variation of oxides of nitrogen with brake power.

Table 3. Specific Heat Combustion Products and Air

\begin{tabular}{cccc}
\hline \multirow{2}{*}{ Produ.cts } & \multicolumn{2}{c}{ Specific heat (in $\mathbf{~ k J / k m o l ~} \mathbf{~ K}$ ) at temperatures of } \\
\cline { 2 - 4 } & $\mathbf{7 2 7}^{\circ} \mathbf{C}$ & $\mathbf{1 , 7 2 7}^{\circ} \mathbf{C}$ & $\mathbf{2 , 7 2 7}^{\circ} \mathbf{C}$ \\
\hline $\mathrm{CO}_{2}$ & 55 & 58.5 & 60 \\
$\mathrm{H}_{2} \mathrm{O}$ & 41 & 50 & 55 \\
Air & 33 & 34.5 & 35.5 \\
\hline
\end{tabular}

\subsection{Soot Emissions}

Fig. 8 depicts the variation of soot emission with brake power for diesel, 20\% JOME, 20\% JOME with 20\% EGR and 20\% JOME with 20\% EGR with DPMCI mode with diesel premix ratio of 0.25. It can be observed that soot emission increases with increase in power output for all the modes due to lower air fuel ratio at higher power outputs as shown in Table 4 . 


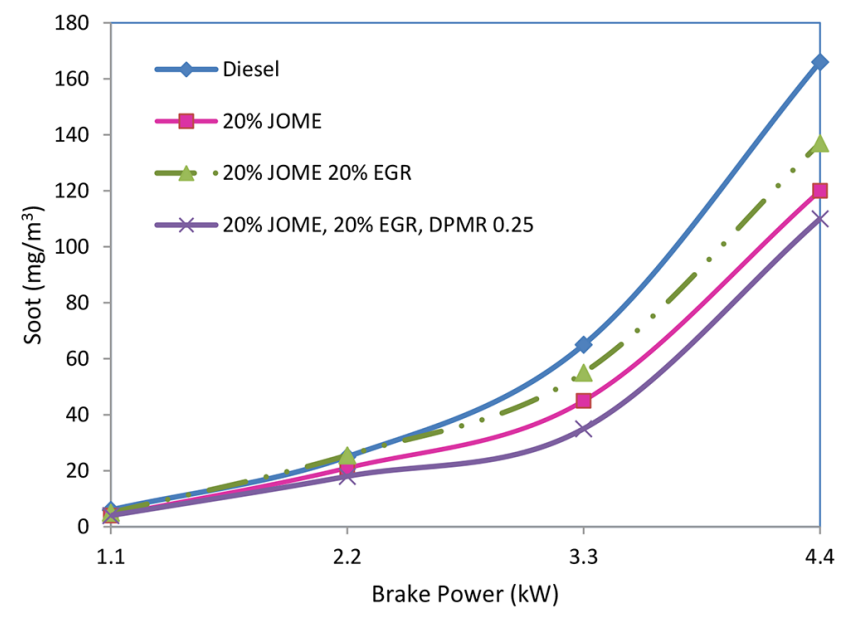

Fig. 8. Variation of soot with brake power.

Table 4. Air Fuel Ratio

\begin{tabular}{ccc}
\hline & $\begin{array}{c}\mathbf{1 0 0} \% \\
\text { Diesel }\end{array}$ & $\begin{array}{c}\mathbf{2 0 \%} \\
\text { JOME }\end{array}$ \\
\hline $\begin{array}{c}\text { Air/Fuel Ratio at 25\% of Rated Power } \\
\text { Output (measured) }\end{array}$ & 54.7 & 51.7 \\
\hline $\begin{array}{c}\text { Air/Fuel Ratio at Rated Power Output } \\
\text { (measured) }\end{array}$ & 24.7 & 23.5 \\
\hline
\end{tabular}

The increase in soot emission is due to reduction in oxygen content and decrease in heat release rate with EGR at all power outputs. It is observed that with $20 \%$ EGR, soot emissions are lower than that of CIDI mode but higher than DPMCI mode. The soot emissions at rated power output for diesel, 20\% JOME with 20\% EGR, 20\% JOME, and 20\% JOME with 20\% EGR with diesel premix ratio of 0.25 are $166 \mathrm{mg} / \mathrm{m}^{3}, 137 \mathrm{mg} / \mathrm{m}^{3}, 120 \mathrm{mg} / \mathrm{m}^{3}$ and $110 \mathrm{mg} / \mathrm{m}^{3}$, respectively. The exhaust gases in the intake air decrease the oxygen content and result in lower combustion temperature. The formation of soot and its oxidation are mainly influenced by the engine operating conditions. The combined effect of fuel properties, lower combustion temperature and lower oxygen content reduces the soot oxidation process which eventually results in higher soot emissions. Fuel rich regions inside the combustion chamber are eliminated in DPMCI mode compared to CIDI mode which results in lower soot emissions.

\subsection{Peak Pressure}

Fig. 9 depicts the variation of peak pressure with brake power in CIDI mode, $20 \%$ JOME mode, DPMCI mode premix ratio of 0.25 with or without $20 \%$ EGR mode. As discussed earlier combustion starts earlier and the peak pressure is high at rated power output. It is observed that the peak pressure decreases with EGR and increases with DPMCI mode. EGR act as a thermal sink controlling the heat release rate and inhibiting rapid pressure rise. Decrease in oxygen content in the charge also contributes to the reduction in peak pressure. The peak pressure in DPMCI mode varies from 61.87 bar lower than any mode but at ration power output 72.86 higher than any modes.

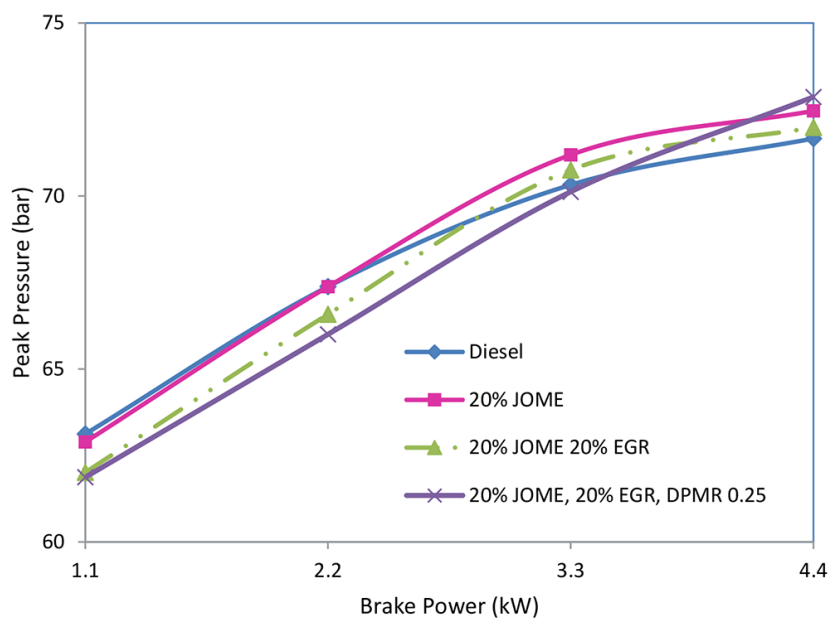

Fig. 9. Variation of peak pressure with brake power.

\subsection{Ignition Delay}

Fig. 10 depicts the variation of ignition delay with brake power in CIDI mode, 20\% JOME mode, DPMCI mode premix ratio of 0.25 with or without $20 \%$ EGR mode. The ignition delay at rated power output for 20\% JOME without EGR and with 20\% EGR is $14.9^{\circ} \mathrm{CA}$ and $15.6^{\circ} \mathrm{CA}$ respectively compared to $15.78^{\circ} \mathrm{CA}$ for diesel engine. The ignition delay at rated power output for $20 \%$ JOME with $20 \%$ EGR and DPMR 0.25 is $15.64^{\circ} \mathrm{CA}$ compared to $15.78^{\circ} \mathrm{CA}$ for diesel engine. The delay period increases marginally due to the reduction in oxygen content.

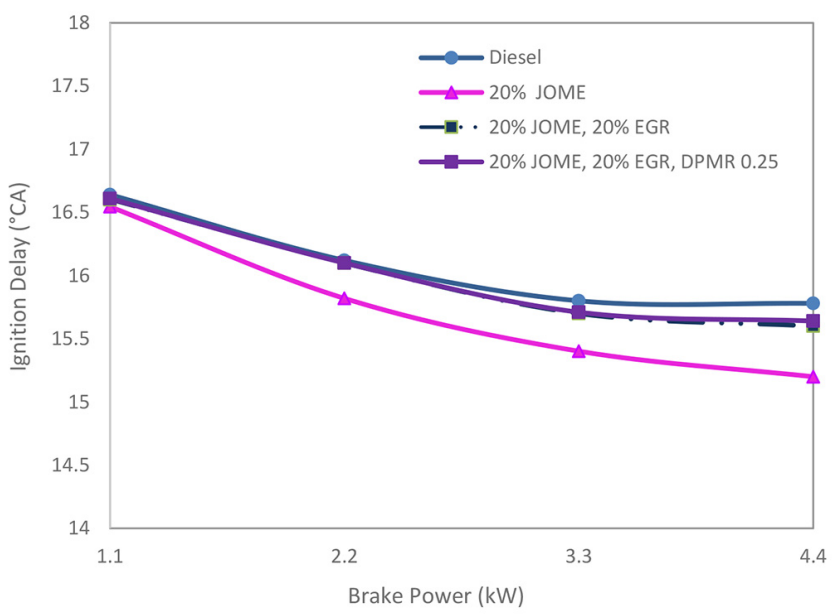

Fig. 10. Variation of ignition delay with brake power.

\section{Conclusions}

In the present work, the performance and emission characteristics of diesel engine fueled with blends of JOME with diesel were investigated. As the premixed charge compression ignition combustion mode is known to simultaneously reduce the Oxides of Nitrogen and Soot, it was taken up for investigation in the present work with $20 \%$ JOME with $20 \%$ EGR with premix ratio of 0.25 . 
The 20\% JOME blends with diesel is a suitable fuel for the diesel engine without major modification in the engine. $\mathrm{NO}_{\mathrm{x}}$ and soot emissions are lower and the percentage decrease in DPMCI mode with $20 \%$ JOME with 0.25 premix ratio are $32 \%$ and $33.73 \%$, respectively compared to CIDI mode. Diesel premix ratio of 0.25 with $20 \%$ EGR is observed to be effective to reduce $\mathrm{NO}_{\mathrm{x}}$ and soot emissions simultaneously, which is primary objective of this research work.

\section{Recommendations}

Biodiesel provides a strategic advantage to promote sustainable development and to supplement conventional energy sources in meeting the rapidly increasing requirements for transportation fuels associated with high economic growth, as well as in meeting the energy needs vast rural population. The renewable energy program should move towards investing, supporting and strengthen the call for clean and renewable energy policies through advocacy and awareness building and creating a supportive renewable energy implementation environment.

\section{References}

1. Owusu PA, Asumadu-Sarkodie S, Dubey S. A review of renewable energy sources, sustainability issues and climate change mitigation. Cogent Eng. 2016;3:1167990.

2. Garg HP, Kandpal TC. Renewable energy education: Challenges and problems in developing countries. Renew. Energ. 1996;9:1188-1193.

3. Demirbas A. Potential applications of renewable energy sources, biomass combustion problems in boiler power systems and combustion related environmental issues. Prog. Energ. Combust. Sci. 2005;31:171-192.

4. El-Kasaby M, Nemit-Allah MA. Experimental investigations of ignition delay period and performance of a diesel engine operated with Jatropha oil biodiesel. Alexandria Eng. J. 2013;52:141-149.

5. Aceves SM, Smith JR, Westbrook CK, Pitz WJ. Compression ratio effect on methane HCCI combustion. J. Eng. Gas Turb. Power 1999;121:569-574.

6. Christensen M, Johansson B, Einewall P. Homogeneous charge compression ignition (HCCI) using isooctane, ethanol and natural gas - A comparison with spark ignition operation. SAE Technical Paper 972874; 1997.

7. Hwang W, Dec JE, Sjöberg M. Fuel stratification for low-load HCCI combustion: Performance \& Fuel-PLIF measurements. Library; 2009. p. 776-790.

8. Mancaruso E, Merola SS, Vaglieco BM. Study of the multi-injection combustion process in a transparent direct injection common rail diesel engine by means of optical techniques. Int. J. Engine Res. 2008;9:483-498.

9. Agarwal D, Singh SK, Agarwal AK. Effect of exhaust gas recirculation (EGR) on performance, emissions, deposits and durability of a constant speed compression ignition engine. Appl. Energ. 2011;88:2900-2907.
10. Su H, Mosbach S, Kraft M, Bhave A, Kook S, Bae C. Two-stage fuel direct injection in a diesel fuelled HCCI engine. SAE Technical Paper 2007-01-1880, 2007.

11. Zhao H, Peng Z, Ladommatos N. Understanding of controlled autoignition combustion in a four-stroke gasoline engine. Proc. Inst. Mech. Eng. D J. Automob. Eng. 2001;215:1297-1310.

12. Lee CS, Lee KH, Kim DS. Experimental and numerical study on the combustion characteristics of partially premixed charge compression ignition engine with dual fuel. Fuel 2003;82: 553-560.

13. Iwabuchi Y, Kawai K, Shoji T, Takeda Y. Trial of new concept diesel combustion system - premixed compression-ignited combustion -. SAE Technical Paper 1999-01-0185, 1999.

14. Park SW, Reitz RD. Numerical study on the low emission window of homogeneous charge compression ignition diesel combustion. Combust. Sci. Technol. 2007;179:2279-2307.

15. Mohamed Ibrahim M, Varuna Narasimhan J, Ramesh A. Comparison of the predominantly premixed charge compression ignition and the dual fuel modes of operation with biogas and diesel as fuels. Energy 2015;89:990-1000.

16. Ma J, Lü X, Ji L, Huang Z. An experimental study of HCCI-DI combustion and emissions in a diesel engine with dual fuel. Int. J. Therm. Sci. 2008;47:1235-1242.

17. Miao H, Jiao Q, Huang Z, Jiang D. Measurement of laminar burning velocities and Markstein lengths of diluted hydrogen-enriched natural gas. Int. J. Hydrogen Energ. 2009;34: 507-518.

18. Murali Manohar R, Prabhahar M, Sendilvelan S. Experimental investigation of combustion and emission characteristics of engine is fueled with diesel and UVOME blends of B20K and B80K. Eur. J. Sci. Res. 2012;76:327-334.

19. Heffel JW. $\mathrm{NO}_{\mathrm{x}}$ emission reduction in a hydrogen fueled internal combustion engine at $3000 \mathrm{rpm}$ using exhaust gas recirculation. Int. J. Hydrogen Energ. 2003;28:1285-1292.

20. Ladommatos N, Balian R, Horrocks R, Cooper L, Co FM. The effect of exhaust gas recirculation on combustion and $\mathrm{NO}_{\mathrm{x}}$ emissions in a high-speed direct-injection diesel engine. SAE Technical Paper 960840, 1996.

21. Abd-Alla GH. Using exhaust gas recirculation in internal combustion engines: A review. Energ. Convers. Manage. 2002;43: 1027-1042.

22. Hountalas DT, Mavropoulos GC, Binder KB. Effect of exhaust gas recirculation (EGR) temperature for various EGR rates on heavy duty DI diesel engine performance and emissions. Energy 2008;33:272-283.

23. Kusaka J. Combustion and exhaust gas emission characteristics of a diesel engine dual- fueled with natural gas. JSAE Rev. 2000;21:489-496.

24. Bai Y long, Wang Z, Wang JX. Part-load characteristics of direct injection spark ignition engine using exhaust gas trap. Appl. Energ. 2010;87:2640-2646.

25. Galloni E, Fontana G, Staccone S. Numerical and experimental characterization of knock occurrence in a turbo-charged spark-ignition engine. Energ. Convers. Manage. 2014;85:417-424.

26. Das LM, Mathur R. Exhaust gas recirculation for $\mathrm{NO}_{\mathrm{x}}$ control in a multicylinder hydrogen-supplemented S.I. engine. Int. J. Hydrogen Energ. 1993;18:1013-1018. 
27. Hussain J, Palaniradja K, Alagumurthi N, Manimaran R. Effect of exhaust gas recirculation (EGR) on performance and emission of a compression ignition engine with staged combustion (Insertion of unburned hydrocarbon). Int. J. Energ. Eng. 2012;2:285-292.

28. Aoyama T, Hattori Y, Mizuta J, Sato Y. An experimental study on premixed-charge compression ignition gasoline engine. SAE Technical Paper 960081, 1996.

29. Saito S, Shinozaki R, Suzuki A, Jyoutaki H, Takeda Y. Development of urea-SCR system for commercial vehicle-basic characteristics and improvement of $\mathrm{NO}_{\mathrm{x}}$ conversion at low load operation. SAE Technical Paper 2003-01-3248, 2003.

30. Singh PJ, Khurma J, Singh A. Preparation, characterisation, engine performance and emission characteristics of coconut oil based hybrid fuels. Renew. Energ. 2010;35:2065-2070.

31. Torregrosa AJ, Broatch A, García A, Mónico LF. Sensitivity of combustion noise and $\mathrm{NO}_{\mathrm{x}}$ and soot emissions to pilot injection in PCCI Diesel engines. Appl. Energ. 2013;104:149-157.

32. Saxena S, Bedoya ID. Fundamental phenomena affecting low temperature combustion and HCCI engines, high load limits and strategies for extending these limits. Prog. Energ. Combust. Sci. 2013;39:457-488.

33. Kiplimo R, Tomita E, Kawahara N, Yokobe S. Effects of spray impingement, injection parameters, and EGR on the combustion and emission characteristics of a PCCI diesel engine. Appl. Therm. Eng. 2012;37:165-175.

34. Labecki L, Ganippa LC. Effects of injection parameters and EGR on combustion and emission characteristics of rapeseed oil and its blends in diesel engines. Fuel 2012;98:15-28.

35. El Diwani G, Attia NK, Hawash SI. Development and evaluation of biodiesel fuel and by-products from jatropha oil. Int. J. Environ. Sci. Technol. 2009;6:219-224.

36. Lapuerta M, Armas O, Rodríguez-Fernández J. Effect of biodiesel fuels on diesel engine emissions. Prog. Energ. Combust. Sci. 2008;34:198-223.

37. Bhaskar K, Sendilvelan S, Muthu V, Aravindraj S. Performance and emission characteristics of compression ignition engine using methyl ester blends of jatropha and fish oil. J. Mech. Eng. Sci. 2016;10:1994-2007.

38. Axelsson L, Franzén M, Ostwald M, Berndes G, Lakshmi G, Ravindranath NH. Perspective: Jatropha cultivation in southern India: Assessing farmers' experiences. Biofuels Bioprod. Biorefin. 2012;6:246-256.

39. Leung DYC, Wu X, Leung MKH. A review on biodiesel production using catalyzed transesterification. Appl. Energ. 2010;87:1083-1095.

40. Kim DS, Lee CS. Improved emission characteristics of HCCI engine by various premixed fuels and cooled EGR. Fuel 2006;85:695-704.

41. Jacobs T, Assanis D, Filipi Z. The impact of exhaust gas recirculation on performance and emissions of a heavy-duty diesel engine. 2003 SAE World Congress; 2003.

42. Shehata MS. Cylinder pressure, performance parameters, heat release, specific heats ratio and duration of combustion for spark ignition engine. Energy 2010;35:4710-4725. 